\title{
Necrotising balanitis due to a generalised primary infection with herpes simplex virus type 2
}

\author{
J. F. PEUTHERER, ISABEL W. SMITH, AND D. H. H. ROBERTSON \\ From the Departments of Bacteriology and Venereology, Edinburgh University Medical School, \\ and the Royal Infirmary, Edinburgh
}

SUMMARY Virological studies have proved herpes simplex virus type 2 to be the cause of the severe primary infection in a 37-year-old man with necrotising balanitis. Symptoms of urethritis preceded the appearance of a severe local lesion; dissemination of infection occurred and lesions developed on the skin of the scalp, neck, trunk, buttocks, arms, legs, and feet. No evidence of involvement of the central nervous system was found, and the penile and skin lesions improved rapidly after the application of $5 \%$ idoxuridine in dimethylsulphoxide. Recurrences occurred at various skin sites at six to seven months after the primary infection.

\section{Introduction}

Almost $90 \%$ of genital infections in men are caused by herpes simplex virus type 2 (HSV-2) strains; in one-third of these patients the HSV-2 infection occurs in the absence of antibody to either HSV-1 or HSV-2 (Smith et al., 1976). We describe an unusually severe primary HSV-2 infection in a 37-year-old man.

\section{Case report}

\section{HISTORY}

A 37-year-old Caucasian man was first seen on 15 January 1976 complaining of pain in the penis and inguinal region, dysuria, and a slight urethral discharge for two days, which had developed about five days after sexual intercourse with an unknown consort. On examination he was noted to have a blood-stained urethral discharge and injection of the meatus. Urine analysis showed protein and glucose. On the basis of the microscopical appearance in the urethral discharge of leucocytes but no organisms a provisional diagnosis of non-specific urethritis was made; the patient was given oxytetracycline $250 \mathrm{mg}$ six-hourly for five days and asked to return four days later on 19 January 1976.

On his return the patient said that he had become less well and that he had attended his own general

Address for reprints: Dr I. W. Smith, Department of Bacteriology, Edinburgh University Medical School, Teviot Place, Edinburgh EH8 9AG

Received for publication 15 August 1978 practitioner complaining of dyspnoea and dizziness. He also said that he had been confused during this period. He was admitted to the ward. On examination there was a shield-shaped blackened area of skin surrounding the urethral meatus and flattened pustules which were irregular in outline and peripheral to this necrotic area (Fig. 1). The glans, prepuce, and shaft of the penis were oedematous; the shaft was hot and reddened with some induration along the urethra. Dome-shaped pustules (Fig. 2) varying in size from $1 \mathrm{~mm}$ to about $7 \mathrm{~mm}$ were widespread over the skin surface and distributed approximately as follows: scalp, one; neck, one; chin, one; trunk, six; buttocks, about 40; scrotum, two; fingers, (right) one and (left) one; shoulder, (right) one; upper arm, nil; thigh and leg, (right) 17 and (left) four; and foot, (right) two and (left) four. The patient was febrile $\left(38.5^{\circ} \mathrm{C}\right)$ and looked unwell. Apart from drowsiness and slight confusion at times no abnormality was noted in the nervous system. A technetium brain scan showed normal uptake without any areas of increased activity to indicate cerebral inflammation or abscess formation. An echo encephalogram showed no shift of midline structures. No abnormality was found in the electroencephalogram.

\section{LABORATORY RESULTS}

The initial erythrocyte sedimentation rate was $74 \mathrm{~mm}$ in the first hour. The white cell count was $7 \cdot 8 \times 10^{9} / 1\left(7 \cdot 8 \times 10^{3} / \mathrm{mm}^{3}\right) ; 69 \%$ neutrophils, $25 \%$ lymphocytes, $5 \%$ monocytes, and $1 \%$ eosinophils. 


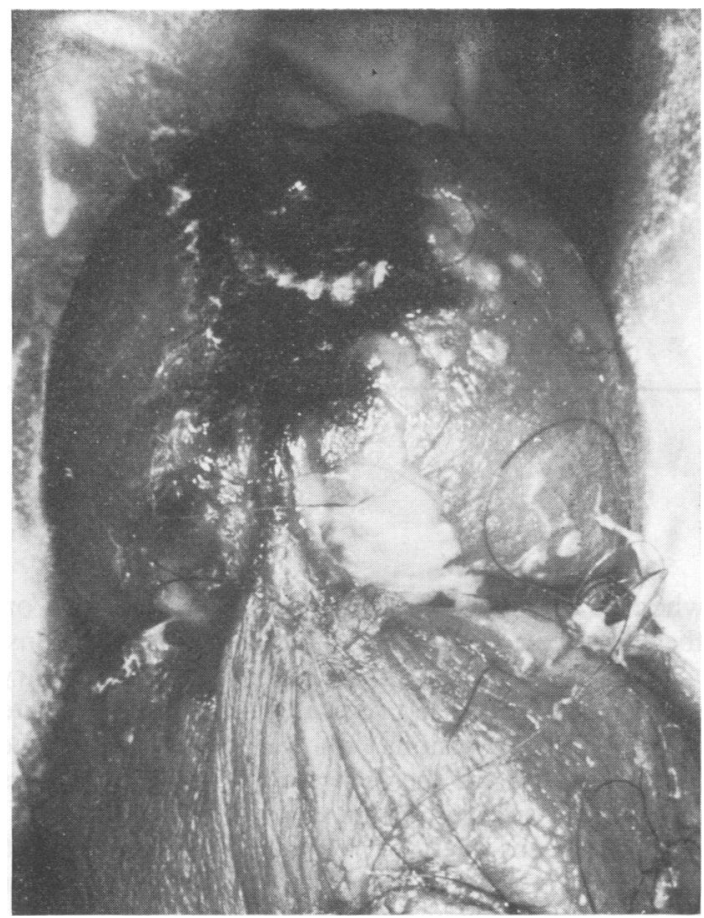

Fig. 1 Penile lesion

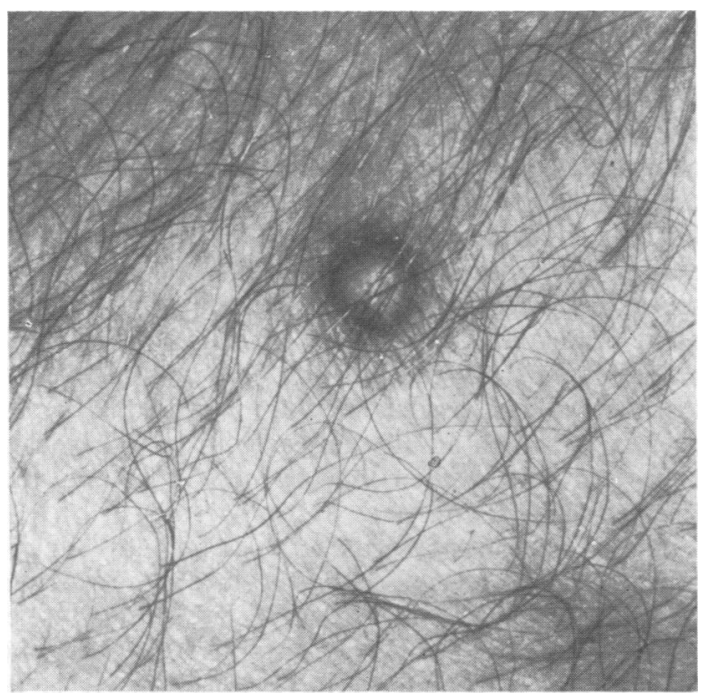

Fig. 2 Dome shaped pustule

Total serum protein, albumin, electrophoretic pattern, and immunoglobulins (IgG, IgM, IgA, and IgE) were within normal limits.

Subsequently he was shown to have a normal population of $\mathrm{T}$ and $\mathrm{B}$ lymphocytes, which gave a good transformation response in culture when stimulated by phytohaemagglutinin (PHA) and conconavalin A (con A). He had positive skin test reactions to purified protein derivative (PPD), mumps, Candida, SKSD, and Trichophyton antigens.

\section{Bacteriology}

Neisseria gonorrhoeae was not isolated and the Venereal Disease Research Laboratory and Treponema pallidum haemagglutination tests gave negative results on the four occasions they were performed over eight months starting on the day of admission.

\section{Virus isolation}

Herpes simplex virus was isolated in human embryo lung cell cultures from swabs of the glans and of a pustule on the thigh on 19 January; from swabs of pustules on the foot, scapular region, and fourth finger (right hand) on 23 January; and from swabs of a neck pustule on 26 January.

Virus isolation was unsuccessful from a urethral scrape on 9 February and from a scrape of the genital lesion and of the fluid and roof of a vesicle on the foot on 24 February.

The isolates were confirmed as type 2 strains by the biological typing features cited by Smith et al. (1973).

\section{Serology}

Serum specimens were collected during the acute illness and up to almost 13 months later. The sera were tested in chessboard titrations against type 1 and type 2 herpes simplex virus antigens in complement-fixation and in neutralisation tests (Smith et al., 1967). The serological conversion measured by the neutralisation test and the significant response shown with both types of complement-fixing antigens established that the patient had a primary herpetic infection (Table). The relative titres of complement-fixing and neutralising antibodies are in agreement with the unpublished observations of Smith and Peutherer.

Analysis of the chessboard complement-fixing titration indicated that the response was greater to the type 2 antigen than to the type 1 antigen. This result is in agreement with the virus type isolated from the patient. Maximal complement-fixing titres of 512 were recorded during the acute illness.

Each serum at a 1/10 dilution was tested by an indirect immunofluorescence test for IgM antibody to HSV-1 and HSV-2; sera with positive results were titrated. Sera gave negative results when tested by a latex agglutination test for rheumatoid factor, and IgM antibody was detected in the lower fraction from a sucrose density gradient $(10-40 \%)$ spun for 16 hours at $100000 \times g$. 
Table Results of serological tests

\begin{tabular}{|c|c|c|c|c|c|c|}
\hline \multirow[b]{2}{*}{ Date of collection } & \multicolumn{3}{|c|}{ Reciprocal titre to $\mathrm{HSV-2}$} & \multicolumn{3}{|c|}{ Reciprocal titre to $H S V-1$} \\
\hline & $N$ & $C F$ & $I g M$ & $N$ & $C F$ & IgM \\
\hline $\begin{array}{c}19 \text { January } 1976 \\
26 \text { January } 1976 \\
9 \text { February } 1976 \\
25 \text { February } 1976 \\
19 \text { August } 1976 \\
3 \text { November } 1976 \\
9 \text { December } 1976 \\
31 \text { January } 1977 \\
7 \text { February } 1977\end{array}$ & $\begin{array}{r}<8 \\
64 \\
256 \\
256 \\
128 \\
\geqslant 256 \\
\geqslant 256 \\
\geqslant 256 \\
\geqslant 256\end{array}$ & $\begin{array}{l}128 \\
512 \\
512 \\
512 \\
256 \\
256 \\
128 \\
256 \\
128\end{array}$ & $\begin{array}{l}320 \\
\text { ND } \\
160 \\
160 \\
<10 \\
<10 \\
<10 \\
<10 \\
<10\end{array}$ & $\begin{array}{l}<8 \\
128 \\
128 \\
128 \\
128 \\
128 \\
256 \\
128 \\
128\end{array}$ & $\begin{array}{r}128 \\
512 \\
512 \\
256 \\
256 \\
256 \\
128 \\
128 \\
64\end{array}$ & $\begin{array}{r}160 \\
\text { ND } \\
80 \\
40 \\
<10 \\
<10 \\
<10 \\
<10 \\
<10\end{array}$ \\
\hline
\end{tabular}

$\mathbf{N}=$ Neutralising antibody

$\mathrm{CF}=$ Complement-fixing antibody

$\mathrm{ND}=$ Not done

Specific IgM antibody was detected during the acute stages of the primary infection and for at least four weeks thereafter (Table).

\section{Histology and electron microscopical examination}

A biopsy specimen of a neck pustule (taken on 26 January) was fixed, stained, and examined in both the light and electron microscopes. Giant cells were seen by light microscopy.

Ultrathin sections were examined in the electron microscope; large numbers of virions were present but no intracellular filaments or microtubules could be detected.

\section{TREATMENT ON ADMISSION}

Cellulitis of the penis and a septicaemia or viraemia were suspected when the patient was admitted to the ward. The fever settled gradually while the patient was on crystalline benzyl penicillin $1 \mathrm{mega}$ unit four-hourly, but his temperature rose to $38.5^{\circ} \mathrm{C}$ after the treatment was changed to ampicillin 500 $\mathrm{mg}$ orally every six hours. Surgical debridement of the penile lesion under anaesthesia had been arranged, but once herpes simplex virus type 2 (HSV-2) had been isolated the penile lesion and the bases of all the opened and evacuated pustules were painted with a $5 \%$ solution of idoxuridine in dimethylsulphoxide. This procedure was repeated three times a day for five days and was followed by very rapid improvement. All pustules began to heal and the penile lesion improved with separation of the necrotic slough. Healing continued gradually and the patient was discharged on 26 February 1976.

\section{PROGRESS}

At follow-up examination on 3 March meatal stenosis was present and this was treated by dilatation. The patient remained well until 9 December, when he developed a cluster of vesicular lesions on the right heel; HSV-2 was isolated from the lesions.

The patient then presented at the end of January with lesions on the left foot and the neck at the site of the primary lesions, on the right side of the abdomen, and on the left ring finger. HSV-2 was recovered from these lesions.

Complement-fixation titres remained at 256 during the period of recurrences; IgM specific for HSV-2 was not detected during this time (Table). The patient has remained symptom free to date.

\section{Discussion}

This patient had an unusually severe infection with HSV-2. The local genital lesion was extensive and necrotic and was comparable in severity to the necrotic cervicitis described by Willcox (1968). Initially, a diagnosis of non-specific urethritis was made. The progression from urethritis to both a severe local lesion and disseminated skin involvement occurred over a period of four days. HSV-2 was isolated from the pustules; this contrasts with the skin lesions associated with gonococcal septicaemia, in which an allergic vasculitis is believed to be important in their pathogenesis (Scherer and Braun-Falco, 1976).

Dissemination of virus from a genital site of infection would be expected to occur only in patients who had not been infected with either virus type. The serological evidence established that the patient had a primary type 2 infection. It is of interest that the reciprocal complement-fixing titres were still elevated (256) one year after the onset. The recurrent episodes within one year of the primary infection are comparable to the pattern of those reported by Yoshino et al. (1962) after primary oral infection with HSV-1. Similarly, the detection of specific IgM during the primary 
infection, but not during the recurrent episodes, is in agreement with previous results (Kurtz, 1974). We have detected IgM antibody, however, in the serum of other patients during recurrences or reinfections with the homologous and heterologous virus types (Smith et al., unpublished data).

Disseminated infection with herpes simplex virus type 2 has been described in a young adult (JuelJensen and MacCallum, 1972). The fatal case described by Sutton et al. (1974) occurred in a 20-year-old woman with dysplasia of the thymus. In our case, an assessment of the patient's humoral and cell-mediated immune responses to various stimuli at the time of the recurrences showed no abnormality. It was not possible to test his response to HSV-1 and HSV-2 antigens. An association between type 2 genital infection, viraemia, and involvement of the central nervous system has been claimed (Craig and Nahmias, 1973), and Skoldenberg and Jeansson (1973) have reported the isolation of type 2 strains of virus from the cerebrospinal fluid of seven patients with acute aseptic meningitis. There was no clear evidence of meningitis or encephalitis in our patient, although he complained of dizziness and confusion during the interval between his first and second visits to the clinic. A lumbar puncture was not performed because the patient's condition began to improve and there were pustules overlying the lumbar spine. The patient's illness was severe enough to consider using a systemic chemotherapeutic agent, but there was a dramatic response to idoxuridine in dimethylsulphoxide applied locally to the penile lesion and pustules. It is possible that prompt treatment with a systemic agent could have prevented infection of the sensory ganglia.

The result of the electron microscope examination of the biopsy specimen of the neck lesion is of interest in that no intracellular filaments or microtubules were found. Filament production has been associated with type 2 strains of virus growing in the chick embryo (Couch and Nahmias, 1969) and BHK cells (Smith et al., 1973). Filaments have been described in HEp2 cells (Schwartz and Roizman, 1969), a cell line of human origin, but Cabral and
Schaffer (1976) failed to detect the structures in cultured human embryo lung cells. The viruses isolated from our patient did produce filaments when grown in BHK and HEp2 cells.

We thank Dr S. J. Urbaniak of the Regional Blood Transfusion Service for arranging the immunological assessment of the patient.

\section{References}

Cabral, G. A. and Schaffer, P. A. (1976). Electron microscope studies of temperature-sensitive mutants of herpes simplex virus type 2. Journal of Virology, 18, 727-737.

Craig, C. P. and Nahmias, A. J. (1973). Different patterns of neurologic involvement with herpes simplex virus types 1 and 2 : Isolation of herpes simplex virus type 2 from the buffy coat of two adults with meningitis. Journal of Infectious Diseases, 127, 365-372.

Couch, E. F., and Nahmias, A. J. (1969). Filamentous structures of type 2 herpesvirus hominis infection of the chorioallantoic membrane. Journal of Virology, 3, 228-232.

Juel-Jensen, B. E. and MacCallum, F. O. (1972). Herpes Simplex Varicella and Zoster, first edition, p 51, Heinemann: London.

Kurtz, J. B. (1974). Specific IgG and IgM antibody responses in herpes-simplex-virus infections. Journal of Medical Microbiology, 7, 333-341.

Scherer, R. and Braun-Falco, O. (1976). Alternative pathway complement activation: a possible mechanism inducing skin lesions in benign gonococcal sepsis. British Journal of Dermatology, 95, 303-309.

Schwartz, J. and Roizman, B. (1969). Similarities and differences in the development of laboratory strains and freshly isolated strains of herpes simplex virus in HEp-2 cells: electron microscopy. Journal of Virology, 4, 879-889.

Skoldenberg, B. and Jeansson, S. (1973). Herpes simplex virus type 2 in acute aseptic meningitis. British Medical Journal, 2, 611.

Smith, Isabel W., Peutherer, J. F., and MacCallum, F. D. (1967). The incidence of Herpesvirus hominis antibody in the population. Journal of Hygiene (Cambridge), 65, 395-408.

Smith, Isabel W., Peutherer, J. F., and Robertson, D. H. H. (1973). Characterization of genital strains of herpesvirus hominis. British Journal of Venereal Diseases, 49, 385-390.

Smith, Isabel W., Peutherer, J. F. and Roberston, D. H. H. (1976). Virological studies in genital herpes. Lancet, 2, 1089-1090.

Sutton, A. L., Smithwick, E. M., Seligman, S. J. and Sung-Sung, K. (1974). Fatal disseminated herpesvirus hominis type 2 infection in an adult with associated thymic displasia. American Journal of Medicine, 56, 545-553.

Willcox, R. R. (1968). Necrotic cervicitis due to primary infection with the virus of herpes simplex. British Medical Journal, 1, 610-612.

Yoshino, K., Taniguchi, S., Furuse, R., Nojima, T., Fujii, R., Minamitani, M., Tada, R., and Kubota, H. (1962). A serological survey for antibodies against herpes simplex virus with special reference to comparatively heat-labile complement-fixing antibodies. Japanese Journal of Medical Science and Biology, 15, 235-247. 